\title{
Fumigant and Non-Fumigant Nematicides Labeled for Agronomic Crops in Florida ${ }^{1}$
}

\section{Zane Grabau²}

Plant-parasitic nematodes can cause severe yield loss of agronomic crops in Florida. Chemical products for managing plant-parasitic nematodes are called nematicides. There are a few nematicides registered for use in Florida; however, some can only be used on one or two agronomic crops. Nematicides must be applied as indicated and can only be applied to the crops listed on the product label. As an aid for Florida growers, nematicide products labeled and available for Florida agronomic crops at the time of publication are listed in Table 1.

Nematicides can be divided into two categories: fumigants and non-fumigants. Fumigants are broad-spectrum pesticides where the active ingredient moves through the soil as a gas. Fumigants are not taken up by plants or bound by soil, so they do not have a long period of residual pesticidal activity. Non-fumigants are formulated in liquid or granular states and are moved through the soil by water. Non-fumigants may have activity against multiple pests, particularly if they contain more than one active ingredient, but generally, they have a narrower spectrum of activity than that of fumigants. Some, but not all, non-fumigant nematicides are systemic, meaning the active ingredient is taken up by the plant and translocated to other parts of the plant. Further information about how nematicides work can be found in EDIS publication ENY-041, Movement and Toxicity of Nematicides in the Plant Root Zone.
There are a variety of different methods by which nematicides are applied, and they must be applied as specified on the label. Fumigant nematicides, and some liquid non-fumigants, may be injected into the soil with a shank or similar equipment. Some nematicides may be applied through irrigation systems, a process called chemigation. Chemigation can only be done through drip irrigation systems for some nematicides, particularly fumigants, while some nematicides, particularly liquid non-fumigants, may be applied through overhead sprinkler irrigation systems. Some liquid non-fumigants may be sprayed onto foliage, onto soil, or into the planting furrow. Depending on the product, granular nematicides may be applied in-furrow, as a broadcast, in a band over the closed furrow, or in a band where the crop will be planted. They must be mechanically incorporated into the soil. Application methods and the activity spectrum for agronomic crop nematicides are summarized in Table 2.

Nematicides are also available as seed treatments for some seed-grown agronomic crops. Generally, the seeds will come pretreated with the nematicidal product, so growers do not have to determine if a product is labeled for a given crop. Seed treatments may protect early growth stages of the crop from nematodes, resulting in some yield increase, but are unlikely to have large impacts on yield or nematode population densities because nematicides applied as a seed treatment are not distributed widely in the soil.

1. This document is ENY065, one of a series of the Department of Entomology and Nematology, UF/IFAS Extension. Original publication date December 2016. Visit the EDIS website at http://edis.ifas.ufl.edu.

2. Zane Grabau, assistant professor, Department of Entomology and Nematology; UF/IFAS Extension, Gainesville, FL 32611.

The Institute of Food and Agricultural Sciences (IFAS) is an Equal Opportunity Institution authorized to provide research, educational information and other services only to individuals and institutions that function with non-discrimination with respect to race, creed, color, religion, age, disability, sex, sexual orientation, marital status, national origin, political opinions or affiliations. For more information on obtaining other UF/IFAS Extension publications, contact your county's UF/IFAS Extension office. 
Table 1. Fumigant and non-fumigant nematicides labeled for specific Florida agronomic crops. ${ }^{1}$

\begin{tabular}{|c|c|c|c|c|c|c|c|c|c|c|}
\hline & \multirow[b]{2}{*}{ Product(s) } & \multirow[b]{2}{*}{ Active ingredients } & \multicolumn{8}{|c|}{ Crop } \\
\hline & & & Corn & Cotton & Peanut & Potato & Soybean & Sorghum & $\begin{array}{l}\text { Sugar- } \\
\text { cane }\end{array}$ & Tobacco \\
\hline \multirow[t]{4}{*}{ Fumigants } & Dominus & Allyl isothiocyanate & & & & yes & & & & \\
\hline & $\begin{array}{l}\text { K-Pam HL, } \\
\text { Sectagon-K54, } \\
\text { Metam KLR }\end{array}$ & Metam Potassium & yes & yes & yes & yes & yes & & & yes \\
\hline & $\begin{array}{l}\text { Telone II, Telone } \\
\text { C17, Telone C35, } \\
\text { InLine, } \\
\text { Pic-Clor 60, Pic- } \\
\text { Clor } 60 \text { EC }\end{array}$ & $\begin{array}{l}\text { 1,3-Dichloropropene } \\
\text { (1,3-D); Chloropicrin } \\
\text { (fungicide) }\end{array}$ & yes & yes & yes & yes & yes & yes & yes & yes \\
\hline & $\begin{array}{l}\text { Vapam HL, } \\
\text { Sectagon-42, } \\
\text { Metam CLR }\end{array}$ & Metam Sodium & yes & yes & yes & yes & yes & & & yes \\
\hline \multirow{7}{*}{$\begin{array}{l}\text { Non- } \\
\text { Fumigants }\end{array}$} & Counter 20G & Terbufos & yes & & & & & yes & & \\
\hline & Majestene & $\begin{array}{l}\text { Dead Burkholderia } \\
\text { bacteria }\end{array}$ & yes & yes & & & yes & & & \\
\hline & Mocap 15G & Ethoprop & yes & & & yes & & & yes & yes \\
\hline & Mocap EC & Ethoprop & & & & yes & & & & \\
\hline & Movento & Spirotetramat & & & & yes & & & & \\
\hline & Velum Total & $\begin{array}{l}\text { Fluopyram, } \\
\text { Imidicloprid } \\
\text { (insecticide) }\end{array}$ & & yes & yes & & & & & \\
\hline & Vydate C-LV ${ }^{3}$ & Oxamyl & & yes & yes & yes & & & & yes \\
\hline \multicolumn{11}{|c|}{$\begin{array}{l}{ }^{1} \text { This information was compiled as a quick reference for commercial Florida agronomic professionals. The mention of a chemical or proprietary } \\
\text { product in this publication does not constitute a written recommendation or an endorsement for its use by the University of Florida, Institute } \\
\text { of Food and Agricultural Sciences, and does not imply its approval to the exclusion of other products or practices that may be suitable. } \\
\text { Products mentioned in this publication are subject to changing state and federal rules, regulations, and restrictions. Product names may } \\
\text { change and additional products may become available or approved for use. Growers have the final responsibility to guarantee that each } \\
\text { product is use legally. }\end{array}$} \\
\hline \multicolumn{11}{|c|}{$\begin{array}{l}{ }^{2} \text { These products have various ratios of 1,3-D to chloropicrin, including 1,3-D without chloropicrin (Telone II). } \\
{ }^{3} \text { At the time of publication, oxamyl was in very limited supply due to production issues. }\end{array}$} \\
\hline
\end{tabular}


Table 2. Properties of fumigant and non-fumigant nematicides labeled for specific Florida agronomic crops. ${ }^{1}$

\begin{tabular}{|c|c|c|c|c|c|c|}
\hline & \multirow[b]{2}{*}{ Product name(s) } & \multirow[b]{2}{*}{$\begin{array}{l}\text { Application } \\
\text { methods }{ }^{1}\end{array}$} & \multirow[b]{2}{*}{ Systemic? } & \multicolumn{3}{|c|}{ Activity against other pathogens or pests } \\
\hline & & & & $\begin{array}{l}\text { Fungal } \\
\text { pathogens }\end{array}$ & Insects & Weeds \\
\hline \multirow[t]{5}{*}{ Fumigant } & Dominus & $\mathrm{I}, \mathrm{D}$ & & yes & & yes \\
\hline & $\begin{array}{l}\text { K-Pam HL, } \\
\text { Sectagon-K54, Metam } \\
\text { KLR }\end{array}$ & $\mathrm{I}, \mathrm{O}, \mathrm{D}$ & & yes & & yes \\
\hline & $\begin{array}{l}\text { Telone II, Telone C17, } \\
\text { Telone C35, Pic Clor } 60\end{array}$ & 1 & & yes $^{2}$ & & yes \\
\hline & $\begin{array}{l}\text { Telone EC, InLine, } \\
\text { Pic Clor } 60 \text { EC }\end{array}$ & $\mathrm{D}$ & & yes & & yes \\
\hline & $\begin{array}{l}\text { Vapam, Sectagon-42, } \\
\text { Metam CLR }\end{array}$ & $\mathrm{I}, \mathrm{O}, \mathrm{D}$ & & yes & & yes \\
\hline \multirow[t]{7}{*}{ Non-fumigant } & Counter 20G & G & yes & & yes & \\
\hline & Majestene & $\mid S, I$ & & & & \\
\hline & Mocap 15G & G & & & yes $^{3}$ & \\
\hline & Mocap EC & SS & & & yes $^{3}$ & \\
\hline & Movento & $\mathrm{FS}, \mathrm{SS}, \mathrm{O}$ & yes & & yes & \\
\hline & Velum Total & IS,O,D & yes & yes & yes & \\
\hline & Vydate C-LV & $\mathrm{FS}, \mathrm{SS}, \mathrm{I} ; \mathrm{O}^{4}$ & yes & & yes & \\
\hline \multicolumn{7}{|c|}{$\begin{array}{l}1 \text { Consult label for legal application methods. I=injection, } \mathrm{D}=\text { application through drip irrigation, } \mathrm{O}=\text { chemigation through overhead sprinkler } \\
\text { irrigation systems, G=granular nematicide incorporated into soil, } \mathrm{FS}=\text { foliar spray, SS=soil spray, IS=in-furrow soil spray }\end{array}$} \\
\hline \multicolumn{7}{|c|}{${ }^{2}$ Has activity against fungal pathogens if chloropicrin is in formulation. Telone II does not include chloropicrin. } \\
\hline \multicolumn{7}{|c|}{${ }^{3}$ Ethoprop products have activity against soil insects only. } \\
\hline \multicolumn{7}{|c|}{${ }^{4}$ Among Florida agronomic crops, oxamyl can only be chemigated on potatoes. } \\
\hline
\end{tabular}

